Eastern Illinois University

The Keep

Faculty Research \& Creative Activity

Biological Sciences

January 2005

\title{
Seed and Seedling Ecology of Acer saccharum and Acer platanoides: A Contrast Between Native and Exotic Congeners
}

Scott J. Meiners

Eastern Illinois University, sjmeiners@eiu.edu

Follow this and additional works at: http://thekeep.eiu.edu/bio_fac

Part of the Biology Commons, and the Plant Sciences Commons

\section{Recommended Citation}

Meiners, Scott J., "Seed and Seedling Ecology of Acer saccharum and Acer platanoides: A Contrast Between Native and Exotic Congeners" (2005). Faculty Research \& Creative Activity. 104.

http://thekeep.eiu.edu/bio_fac/104 
2005 NORTHEASTERN NATURALIST 12(1):23-32

\title{
Seed and Seedling Ecology of Acer saccharum and Acer platanoides: A Contrast Between Native and Exotic Congeners
}

\author{
SCOTt J. Meiners ${ }^{1}$
}

\begin{abstract}
The exotic tree, Acer platanoides, is increasing in forests of northeastern North America, largely within the range of its native congener, Acer saccharum. A combination of field and controlled experiments was used on seeds and seedlings of these congeners to determine species characteristics that may be contributing to these floristic changes. Acer platanoides experienced lower rates of seed predation than A. saccharum in field experiments. Differences in the dispersal and allocation characteristics of the two species were small and not likely to explain the relative success of $A$. platanoides. Greenhouse-grown seedlings of $A$. platanoides were much larger than those of $A$. saccharum because of differences in seed size, not differences in growth rate. These data suggest that preferential seed predation and initial seed size differences may explain greater relative success in Acer platanoides seedlings.
\end{abstract}

\section{Introduction}

Exotic species invasions are a problem of global concern due to huge costs for control and eradication (Pimentel et al. 2000) as well as potential impacts on natural ecosystems (Parker et al. 1999). For these reasons, factors that contribute to success of a species as an invader are of extreme importance in predicting potential invasions and in determining appropriate management strategies (Rejmánek 1999). Comparing native and exotic congeners provides a useful framework to determine characteristics contributing to invasiveness while accounting for similar evolutionary histories (Collins and Wein 1993, Schierenbeck et al. 1994, Van Clef and Stiles 2001). In this study, I compare the exotic Acer platanoides L. to the native Acer saccharum Marshall to better understand the spread and increase of A.platanoides in forests of northeastern North America.

Acer platanoides, a native of continental Europe, is commonly planted as a shade tree in North America because of its disease resistance, tolerance of poor soils, and overall attractiveness (Webb et. al 2000). From widespread horticultural plantings, this species has colonized natural areas throughout the eastern United States and now commonly occurs across a gradient of forest types from urban woodlots to

${ }^{1}$ Department of Biological Sciences, Eastern Illinois University, 600 Lincoln Avenue, Charleston, IL 61920-3099; cfsjm2@eiu.edu. 
relatively undisturbed old-growth forests (Anderson 1999, Martin 1999, Webb and Kaunzinger 1993, Webb et al. 2000). Invasion of forests by A. platanoides is associated with declines in understory species richness and in native tree regeneration (Martin 1999, Webb et al. 2001, Wyckoff and Webb 1996). The seedling pool of these forests is also dominated by A. platanoides, indicating that abundance of this species is likely to increase in the future (Webb et al. 2000, Wyckoff and Webb 1996).

Both Acer saccharum and A. platanoides are shade tolerant canopy trees characteristic of closed-canopy, often late successional, forests (Kloeppel and Abrams 1995, Lei and Lechowicz 1998, Webb et al. 2000). Both of these species primarily regenerate by forming seedling banks, remaining as seedlings in the understory for extended periods until a canopy opening occurs (Marks and Gardescu 1998, Webb et al. 2001). When these two congeners co-occur within forests, A. saccharum regeneration is inhibited (Martin 1999, Webb et al. 2001, Wyckoff and Webb 1996), presumably through competitive interactions. As the composition of the seedling bank determines which species will be available to recruit into a canopy opening, factors that determine the relative abundance of seedlings in the understory may regulate the composition of canopy recruitment.

As A. platanoides expands its range, interactions between these two congeners may become more widespread, increasing the prevalence of this invasions' influence on forest dynamics. I used a series of experiments to compare seed and seedling stages of A. saccharum and A. platanoides to determine the autecological mechanism(s) contributing to the contemporary shift in species composition occurring in North American forests. I examined seed dispersal, seed predation, germination, and seedling growth and biomass allocation.

\section{Methods}

\section{Seed collection and storage}

Seeds of A. saccharum were collected on 1 September 2000 from 5 trees on Rutgers Cook College campus (New Brunswick, NJ). Acer platanoides seeds were collected on 10 September 2000 from 12 individuals in a naturalized population on Rutgers Cook College campus. Seeds were sorted to remove damaged or unfilled fruits. Seeds were stored dry under refrigeration $\left(5^{\circ} \mathrm{C}\right)$ until they were stratified following Young and Young (1992).

\section{Seed dispersal}

To evaluate relative potential for dispersal by wind, the terminal velocity of samaras was calculated for each species. Slower terminal 
velocities result in greater potential dispersal distance (Guries and Nordheim 1984). Undamaged samaras of both species $(n=120)$ were dropped in a laboratory from heights of $2,3,4$, and $5 \mathrm{~m}$, and the time of descent recorded. Seeds were released from the same orientation as on a maternal tree. Linear regression was used to determine the slope of the linear portion of the data, which represents the constant rate of descent once terminal velocity has been reached (Thompson 1993).

\section{Seed predation}

Three forest stands within $0.6 \mathrm{~km}$ of each other were selected within the Hutcheson Memorial Forest (East Millstone, NJ; 40³0'N, $\left.74^{\circ} 34^{\prime} \mathrm{W}\right)$. All stands were approximately 45 years old and did not contain either Acer species at the time of the experiment, although both species were found within adjacent areas of the forest. This site selection would therefore assess seed predation in newly invaded habitats and would also prevent contamination of the experiment from external seed sources. The three stands varied in structure and composition and included: 1) a dense Juniperus virginiana L. stand with little understory; 2) a J. virginiana woodland with scattered Malus sp. and Rosa multiflora Thunb.; and 3) a mixed stand dominated by Fraxinus americana L., Quercus palustris Muenchh. and Acer rubrum. L. Two of these sites had a closed canopy, while the $J$. virginiana woodland had a few canopy gaps. Based on capture data at the site, the numerically dominant predators of woody plant seeds are white-footed mice, Peromyscus leucopus Rafinesque (Manson and Stiles 1998, Pearson 1959), which are abundant in both old fields and forests of northeastern North America.

Forty seed dishes were placed at $1-\mathrm{m}$ intervals along a transect within each stand. Open-topped dishes $(14 \times 14 \times 1 \mathrm{~cm})$ made of black aluminum screening were anchored to the soil with a galvanized nail. Within each dish, 10 seeds (the entire samara) of either Acer saccharum or Acer platanoides were placed on 9 October 2000. Species were assigned randomly to each dish resulting in 20 dishes of each species along each transect. Seed removal was censused for all dishes on days 5 , $10,15,20$, and 30 . At each census, a radius of $30 \mathrm{~cm}$ around each dish was searched for missing seeds and predator-removed hulls. Most intact seeds dislodged from these dishes are found immediately next to the dish, while hulls tend to move greater distances (S.J. Meiners, pers. observ.). Any seed not located within $30 \mathrm{~cm}$ of the dish or located as depredated remains was assumed to have been removed by a predator that cache seeds in the fall.

To further understand predation differences between species, seed removal data were separated into seed encounter and seed exploitation 
components (Hulme 1994, Meiners and LoGiudice 2003), representing separate steps in the predation process (Hulme 1993). Encounter was defined as the time until the first seed was removed from a dish while exploitation was defined as the rate at which seeds were removed from dishes following encounter. It should be noted that encounter rates are conservative estimates, as dishes located by predators that did not remove any seeds would not be documented. Seed removal (overall seed survivorship), encounter, and exploitation data were analyzed with survival analyses (Cox regressions, Proc PHREG; SAS Institute Inc. 1989) to determine differences between species. These analyses integrate the number of events occurring (e.g., seed removal) with the time for that event to occur to generate a relative risk (Fox 2001, Meiners and LoGiudice 2003). In all analyses, data were stratified by site to remove inter-site variation in removal rates and thereby focus on differences between species.

\section{Greenhouse experiment}

A greenhouse experiment was conducted to compare potential emergence, growth, and allocation patterns. On 26 January 2001, fifteen stratified seeds of either A. saccharum or A. platanoides were planted in 15-cm standard pots filled with Pro-mix (Premier Horticulture Ltd., Dorval, QP) sterile growing medium. A total of 24 pots of each species were planted and placed randomly on a bench in the greenhouse of Eastern Illinois University. Pots were watered to saturation as necessary and placed under supplemental lighting to extend the photoperiod to 12 h. This lighting regime delivered a total PAR of approximately $9.0 \mathrm{~mol} /$ $\mathrm{m}^{2} /$ day, roughly equivalent to the total light reaching the forest floor in eastern deciduous forests (Bazzaz 1996). To determine the impacts of seed mass on growth rates, a sample of 110 seeds of each species was removed from their samaras, dried, and weighed.

Emergence was assessed after 28 days, at which time seedlings were thinned to a maximum of five per pot (resulting in an average of 3.8 seedling per pot at harvest). Differences between species in the number of seedlings emerging per pot were analyzed with a Wilcoxon ranksums test. After 63 days the surviving seedlings were harvested and all soil rinsed from their roots. Total leaf area was measured with a LI-3100 area meter (LICOR Inc., Lincoln, NE). Seedlings were dried at $70{ }^{\circ} \mathrm{C}$ for 3 days, divided into root, stem, and leaf portions, and weighed. From these data, leaf area ratio (leaf area/total seedling biomass) and root:shoot ratio were calculated. Mean seed mass of each species was used to calculate relative growth rates with the formula: [ln (seedling mass) - In (seed mass)]/ 9 weeks. Pot means were analyzed with ANOVA to determine the significance of species differences in growth and biomass allocation patterns. 


\section{Results}

\section{Seed dispersal}

The mass of A. platanoides seeds was $65 \%$ greater than that of A. saccharum (Fig. 1a; ANOVA: $\mathrm{F}_{1,218}=115.83 ; \mathrm{P}<0.0001$ ). Time of descent for each species was linear between 3 and $5 \mathrm{~m}$ and was used to calculate terminal velocity. Despite greater seed mass,

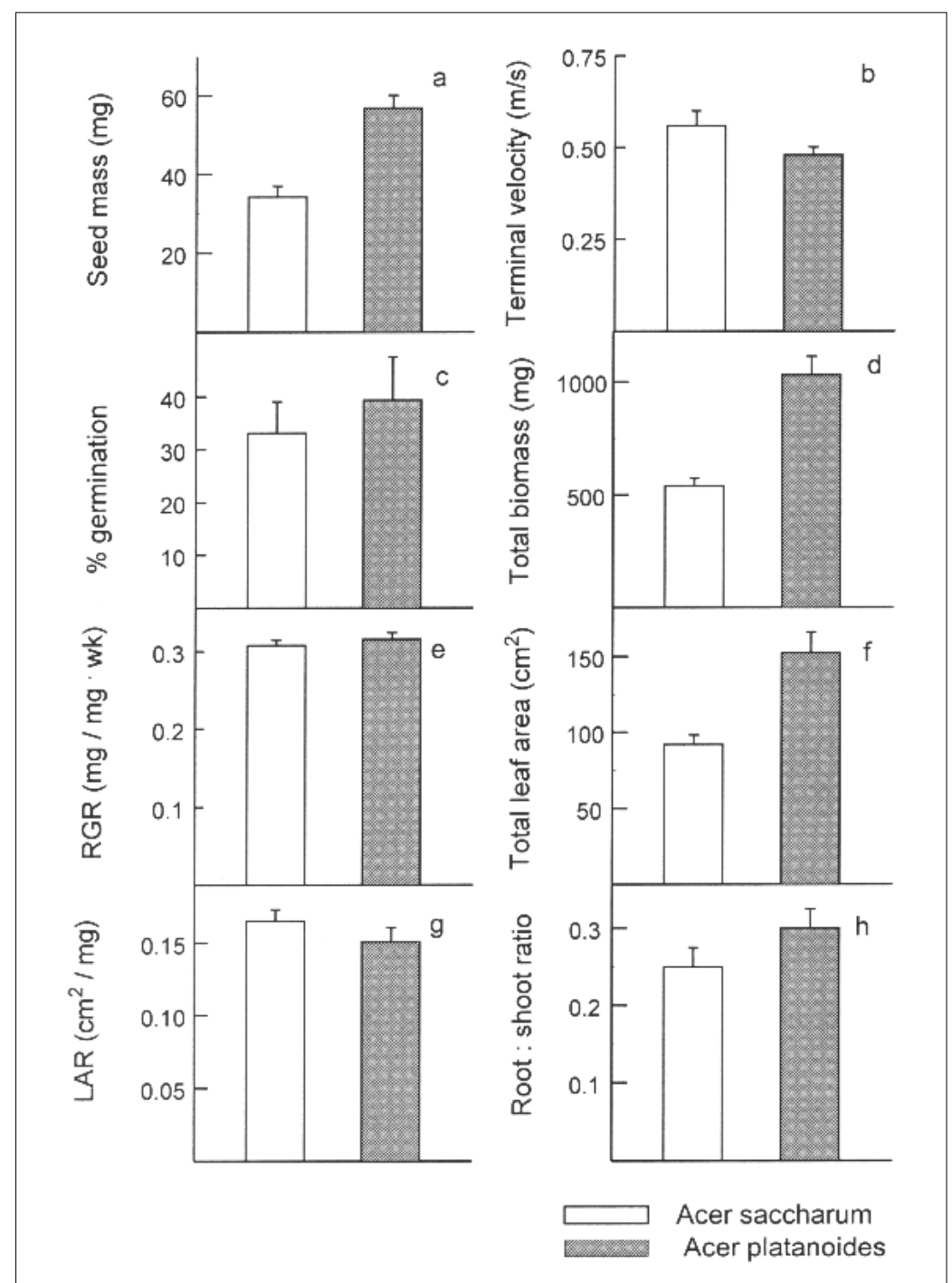

Figure 1. Comparison of the physical traits and allocation patterns of A. saccharum and A. platanoides seeds and seedlings. Values plotted are means for each species, with error bars representing $95 \%$ confidence intervals. Abbreviations in figure: $\mathrm{RGR}=$ relative growth rate; $\mathrm{LAR}=$ leaf area ratio. 
A. platanoides had the slower terminal velocity when compared to $A$. saccharum (Fig. 1b; P < 0.0001).

\section{Seed predation}

For both species combined, $79.2 \%$ of all seeds that were removed were found as discarded seed hulls, verifying predator activity in the three forest stands. Overall, A. platanoides experienced a slower rate of seed removal than A. saccharum (Fig. 2). Risk of predation for the native $A$. saccharum was $1.63 \times(95 \%$ CI 1.43-1.86) that of the exotic A. platanoides (Wald $\chi^{2}=54.21 ; \mathrm{df}=1 ; \mathrm{P}<0.0001$ ). Species differences were also significant when separated into encounter and exploitation rates. Risk of encounter for dishes containing A. saccharum was $1.78 \times(95 \%$ CI $1.17-2.70)$ that of dishes containing $A$. platanoides (Wald $\chi^{2}=7.28 ; \mathrm{df}=1 ; \mathrm{P}=0.007$ ). Similarly, seed exploitation following encounter was greater in A. saccharum with risk of removal $1.18 \times(95 \%$ CI $1.03-1.35)$ that of A. platanoides (Wald $\chi^{2}=5.80 ; \mathrm{df}=1 ; \mathrm{P}=0.016$ ).

\section{Greenhouse experiment}

Germination of stratified seeds did not differ significantly between the two congeners (Fig. 1c; Wilcoxon rank sums test: $\chi^{2}=1.32 ; \mathrm{df}=1$; $\mathrm{P}=0.25$ ). Seedlings of $A$. platanoides were $98 \%$ larger (ANOVA: $\mathrm{F}_{1,43}=$ 29.62; $\left.\mathrm{P}<0.001 ; \mathrm{R}^{2}=0.41\right)$ and had a greater total leaf area (ANOVA: $\mathrm{F}_{1,43}=18.16 ; \mathrm{P}<0.001 ; \mathrm{R}^{2}=0.30$ ) than seedlings of A. saccharum (Fig. 1d-f). However, relative growth rate did not vary between species (ANOVA: $\mathrm{F}_{1,43}=0.542 ; \mathrm{P}=0.46 ; \mathrm{R}^{2}=0.01$ ). Neither assessment of biomass allocation differed between the two species (Figs. 1g,h), with both root: shoot ratio (ANOVA: $\mathrm{F}_{1,43}=2.22 ; \mathrm{P}=0.14 ; \mathrm{R}^{2}=0.05$ ) and leaf area ratio (ANOVA: $\mathrm{F}_{1,43}=1.34 ; \mathrm{P}=0.25 ; \mathrm{R}^{2}=0.03$ ) having nonsignificant differences.

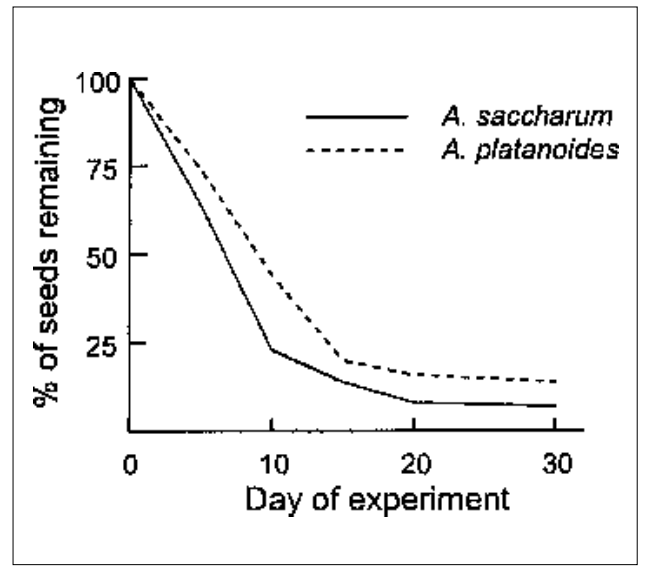

Figure 2. Seed removal of $A$. platanoides and A. saccharum subjected to seed predators. Data are pooled across all three experimental sites and incorporate both encounter and subsequent exploitation of seeds. 
Discussion

Differences in seed dispersal and allocation patterns appear insufficient to explain the current transition from native A. saccharum to exotic A. platanoides species in many northeastern forests. The slower terminal velocity for $A$. platanoides seeds would result in potential for a slightly greater dispersal distance in closed-canopy forests and may result in differential colonization of unoccupied sites (Guries and Nordheim 1984). However, both species develop persistent seedling banks (Webb et al. 2001), reducing dependence on yearly seed inputs for successful regeneration. Both species also appear to show marked annual fluctuations in seed production with large seed crops followed by one or more years of relatively small crops (S.J. Meiners, pers. observ.; USDA 1990).

Early seedling biomass allocation patterns were also very similar between the two species. Lei and Lechowicz (1998) found relatively small differences between A. saccharum and A. platanoides in photosynthetic traits and allocation patterns across a range of light levels (from 1.5 to $20 \%$ full sun), particularly compared to the variation found across the genus Acer. Studies of the physiological characteristics of cooccurring native Acer species find much larger differences among species, resulting in differential success in heterogeneous habitats (Sipe and Bazzaz 1995). The overall similarity in the physiology and allocation patterns of the two species in this study indicates adaptions for very similar environmental conditions.

At the end of the greenhouse experiment, A. platanoides seedlings were nearly twice the mass of A. saccharum. However, this size difference is not the result of differences in relative growth rates as they are nearly identical between the two species after accounting for differences in seed size (Fig. 1e). This suggests that initial size at the seed stage accounts for greater final biomass. Larger seeds can confer tree seedlings with an increased ability to establish under shaded conditions, withstand environmental stresses, and tolerate herbivory (Jurado and Westoby 1992, Saverimuttu and Westoby 1996). The larger seeds of $A$. platanoides may therefore allow the species to establish across a wider range of environmental conditions. Furthermore, resulting size differences in seedlings may allow A. platanoides to compete more effectively with other seedlings in the forest understory. Acer platanoides seedlings typically dominate the understories beneath both A. saccharum and A. platanoides canopy trees (Martin 1999, Webb et al. 2001, Wyckoff and Webb 1996)

This study finds clear evidence of differential seed predation that favors survival of the exotic congener. This effect appears to be a combination of differences in encounter rates and subsequent removal 
of seeds of the two species. Differences in seed encounter rates suggest that the local seed predators may not have immediately recognized $A$. platanoides as a suitable food source or that they were not actively searching for seeds of this species. In contrast, predators located dishes of natives at faster rates. Differences between the congeners in removal following encounter were much smaller, but still significantly favored survivorship of the exotic species. Species preference may result from the milky latex associated with A. platanoides tissues (Webb et al. 2000), which may make seeds distasteful. Differential predation rates between these congeners indicate the potential for seed predation to determine future composition of canopy trees in these communities (Hulme 1996, Pyke 1990).

This study suggests that the larger size and reduced predation of $A$. platanoides seeds enables this species to differentially invade forests at early demographic stages. These findings, in combination with the apparent competitive ability (Martin 1999, Webb et al. 2001, Wyckoff and Webb 1996) and positive response to disturbance (Anderson 1999) of A. platanoides, help to provide mechanisms explaining this species' spread throughout northeastern North America.

\section{Acknowledgments}

I thank the Department of Biological Sciences, Eastern Illinois University, for financial support, and Steve Malehorn for assistance in the greenhouse. Previous versions of this manuscript benefited from comments by C.L. Pederson, A.S. Methven and R. Widinski. All greenhouse and laboratory work was conducted by the sprin,g 2001 Plant Ecology class at Eastern Illinois University.

\section{Literature Cited}

Anderson, R. 1999. Disturbance as a factor in the distribution of sugar maple and the invasion of Norway maple into a modified woodland. Rhodora 101:264-273.

Bazzaz, F.A. 1996. Plants in Changing Environments. Cambridge University Press, Cambridge, UK.

Collins, B., and G.R. Wein. 1993. Competition between native and immigrant Polygonum congeners. Canadian Journal of Botany 71:939-945.

Fox, G.A. 2001. Failure-time analysis: Studying times to events and rates at which events occur. Pp. 235-266, In S.M. Scheiner and J Gurevitch (Eds.). Design and Analysis of Ecological Experiments. Oxford University Press. Oxford, UK.

Guries, R.P., and E.V. Nordheim. 1984. Flight characteristics and dispersal potential of maple samaras. Forest Science 30:434-440.

Hulme, P.E. 1993. Post-dispersal seed predation by small mammals. Symposium of the Zoological Society of London 65:269-287.

Hulme, P.E. 1994. Post-dispersal seed predation in grassland: Its magnitude and sources of variation. Journal of Ecology 82:645-652. 
Hulme, P.E. 1996. Herbivory, plant regeneration, and species coexistence. Journal of Ecology 84:609-615.

Jurado, E., and M. Westoby. 1992. Seedling growth in relation to seed size among species of arid Australia. Journal of Ecology 80:407-416.

Kloeppel, B.D., and M.D. Abrams. 1995. Ecophysiological attributes of the native Acer saccharum and the exotic Acer platanoides in urban oak forests in Pennsylvania, USA. Tree Physiology 15:739-746.

Lei, T.T., and M.J. Lechowicz. 1998. Diverse responses of maple seedlings to forest light regimes. Annals of Botany 82:9-19.

Manson, R.H., and E.W. Stiles. 1998. Links between microhabitat preferences and seed predation by small mammals in old fields. Oikos 82:37-50.

Marks, P.L., and S. Gardescu. 1998. A case study of sugar maple (Acer saccharum) as a forest seedling bank species. Journal of the Torrey Botanical Society. 125: 287-296.

Martin, P.H. 1999. Norway maple (Acer platanoides) invasion of a natural forest stand: Understory consequence and regeneration pattern. Biological Invasions 1:215-222.

Meiners, S.J., and K. LoGiudice. 2003. Temporal consistency in the spatial pattern of seed predation across a forest-old field edge. Plant Ecology 168:45-55.

Parker, I.M., D. Simberloff, W.M. Lonsdale, K. Goodell, M. Wonham, P.M. Kareiva, M.H. Williamson, B. Von Holle, P.B. Moyle, J.E. Byers, and L. Goldwasser. 1999. Impact: Toward a framework for understanding the ecological effects of invaders. Biological Invasions 1:3-19.

Pearson, P.G. 1959. Small mammals and old field succession on the Piedmont of New Jersey. Ecology 40:249-255.

Pimentel, D., L. Lach, R. Zuninga, and D. Morrison. 2000. Environmental and economic costs of nonindigenous species in the United States. BioScience 50:53-65.

Pyke, D.A. 1990. Comparative demography of co-occurring introduced and native tussock grasses: Persistence and potential expansion. Oecologia 82:537-543.

Rejmánek , M. 1999. Invasive plant species and invasible ecosystems. Pp. 79102, In O.Y. Sandlund, P.J. Schei, and A. Viken (Eds.). Invasive Species and Biodiversity Management. Kluwer Academic Publishers, Dordrecht, Netherlands.

SAS Institute Inc. 1989. SAS/STAT User's Guide, Version 6, Fourth Edition, Vol.1 and 2. SAS Institute Inc., Cary, NC.

Saverimuttu, T., and M. Westoby. 1996. Seedling longevity under deep shade in relation to seed size. Journal of Ecology 84:681-689.

Schierenbeck, K.A., R.N. Mack, and R.R. Sharitz. 1994. Effects of herbivory on growth and biomass allocation in native and introduced species of Lonicera. Ecology 75:1661-1672.

Sipe, T.W., and F.A. Bazzaz. 1995. Gap partitioning among maples (Acer) in central New England: Survival and growth. Ecology 76:1587-1602.

Thompson, K. 1993. Seeds: Buoyancy in air. Pp. 176-178, In G.A.F. Hendry and J.P. Grime (Eds.). Methods in Comparative Plant Ecology, $1^{\text {st }}$ Edition. Chapman and Hall, London, UK. 
USDA. 1990. Silvics of North America., Vol. 2. Hardwoods Edition. USDA Forest Service, Washington, DC.

Van Clef, M., and E.W. Stiles. 2001. Seed longevity in three pairs of native and non-native congeners: Assessing invasive potential. Northeastern Naturalist 8:301-310.

Webb, S.L., and C.M.K. Kaunzinger. 1993. Biological invasion of the Drew University Forest Preserve by Norway maple (Acer platanoides L.). Bulletin of the Torrey Botanical Club 120:342-349.

Webb, S.L., M. Dwyer, C.K. Kaunzinger, and P.H. Wyckoff. 2000. The myth of the resilient forest: Case study of the invasive Norway maple (Acer platanoides). Rhodora 102:332-354.

Webb, S.L., T.H. Pendergast IV, and M.E. Dwyer. 2001. Response of native and exotic maple seedling banks to removal of the exotic, invasive Norway maple (Acer platanoides). Journal of the Torrey Botanical Society 128:141-149.

Wyckoff, P.H., and S.L. Webb. 1996. Understory influence of the invasive Norway maple (Acer platanoides). Bulletin of the Torrey Botanical Club 123:197-205.

Young, J.A., and C.G. Young. 1992. Seeds of Woody Plants in North America. Dioscorides Press, Portland, OR. 